\title{
Mineralogy and geochemistry of clay layers and partings from the Maritsa East lignite basin, Bulgaria
}

\author{
D. Dimitrova ${ }^{1 *}$, S. GeORGIEV $^{1}$, M. Vetseva ${ }^{1}, \mathrm{M}$. \\ YOSSIFOVA $^{1}$, Y. TZVETANOVA ${ }^{2}$ AND R. IVANOVA ${ }^{1}$
}

${ }^{1}$ Geological Institute, Bulgarian Academy of Sciences, 1113, Sofia, Bulgaria (didi@geology.bas.bg)

${ }^{2}$ Institute of Mineralogy and Crystallograohy, Bulgarian Academy of Sciences, 1113, Sofia, Bulgaria

The Maritsa East lignite basin is located in the easternmost part of the Late Alpine Upper Thrace depression (SE Bulgaria). The Late Oligocene-Miocene Maritsa Formation is composed of black, gray, and grayish-green clays interlayered with three lignite seams. The medium lignite seam (15-28 m thickness) is interbedded with thin (5$15 \mathrm{~cm})$ beige white silty-clayey parting layers $(\operatorname{Tr} 1-2$ and TrN-3). The clays contain mainly montmorillonite, kaolinite, and quartz with minor mica, plagioclase, $\mathrm{K}$-feldspar, calcite (mollusk shells), accessory apatite (fish bones), framboidal pyrite, zircon, and coal matter. The Tr1-2 and TrN-3 slightly differ in mineralogy: with dominant kaolinite and plagioclase, as TrN-3 also have mica, K-feldspar, chlorite, and montmorillonite. Major element oxides are $\mathrm{SiO}_{2}$ and $\mathrm{Al}_{2} \mathrm{O}_{3}$, except two samples enriched in $\mathrm{CaO}$ (6.3 and 22.6 wt.\%, with Ctot - 12.9-13 wt.\%) due to the presence of mollusk shells. Total $\mathrm{S}$ is ranging from 0.3 to $1.6 \mathrm{wt} . \%$. The $\mathrm{P}_{2} \mathrm{O}_{5}$ is highest in the clays containing fish fossil remains $(0.2-0.5 \mathrm{wt} . \%)$. The $\mathrm{Fe}_{2} \mathrm{O}_{3}$ is 2.7 to 7.6 wt.\%, lowest in $\operatorname{Tr} 1-2-0.7$ wt.\%. The $\mathrm{TiO}_{2} / \mathrm{Al}_{2} \mathrm{O}_{3}$ is $0.03-0.04$, suggesting origin from resedimented intermediate rocks. The low $\mathrm{TiO}_{2} / \mathrm{Al}_{2} \mathrm{O}_{3}$ of $\mathrm{Tr} 1-2(0.004)$ denotes an acid volcanic ash origin [1]. The clay layers and partings are enriched in $\mathrm{Ba}, \mathrm{Rb}, \mathrm{Sr}, \mathrm{Zr}, \mathrm{V}, \mathrm{Cr}, \mathrm{Ni}, \mathrm{Cu}, \mathrm{Zn}$, and $\mathrm{Pb}$. The $\mathrm{Th} / \mathrm{U}$ is from 1.4 to 4.6 and $\mathrm{U}$ and $\mathrm{Th}$ are in the range (ppm) of 1.2-12.8 and 2.6-23.9, respectively. Total REY content is from 34 ( $\operatorname{Tr} 1-2)$ to $353 \mathrm{ppm}(\mathrm{TrN}-3)$, usually 120 $220 \mathrm{ppm}$ (black and grayish-green claystones), which defines them as not promising for REY extraction. The upper continental crust normalized REY patterns, $\mathrm{La}_{N} / \mathrm{Lu}_{N}$, $\mathrm{La}_{N} / \mathrm{Sm}_{N}$, and $\mathrm{Gd}_{N} / \mathrm{Lu}_{N}$ attribute most clays to the mixed L-M type, whereas Tr1-2 shows characteristics of the H-type [2]. The weak positive $\mathrm{Eu} / \mathrm{Eu}^{*}(1.1-1.4)$ and negative $\mathrm{Ce} / \mathrm{Ce}^{*}$ (0.8-0.9) anomalies can be explained with Eu scavenging of basin water in slightly reduced deposition conditions [3].

[1] Addison et al. (1983) Int. J. Coal Geol. 3, 1-30. [2] Seredin \& Dai (2012) Int. J. Coal Geol. 94, 76-93. [3] Dai et al. (2016) Int. J. Coal Geol. 159, 82-95. 